Innlegg på inntil $\mathbf{4 0 0}$ ord lastes opp i http://mc.manuscriptcentral.com/tidsskriftet.

Redaksjonen forbeholder seg retten til å foreta redaksjonelle endringer.

Forfattere av vitenskapelige artikler har tilsvarsrett (jf. Vancouver-gruppens regler).

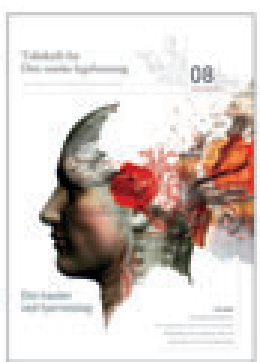

\section{Ikke enten - eller, men både - og i slagmedisinen}

I Tidsskriftet nr. 8/2011 står to interessante artikler om hjerneslag i Bergen $(1,2)$ ledsaget av en lederartikkel (3). Langt på vei er slagbehandlingen ved Oslo universitetssykehus bygd opp etter de samme prinsipper som på Haukeland universitetssykehus.

Også vi registrerer en økning i andelen lakunære slag, liggetiden er redusert, og vi er helt enige $i$ at reperfusjonsbehandling skal tilbys alle aktuelle pasienter samt at de med transitorisk iskemisk anfall (TIA) bør innlegges.

Artiklene reiser også noen andre problemstillinger. Det er overraskende at man på Haukeland universitetssykehus finner en mye lavere insidens av hjerneslag enn hva som er funnet ellers i Norge. Haraldsplass Diakonale Sykehus oppgir at de i 2010 behandlet 238 hjerneinfarkter fra en lokalsykehuspopulasjon på ca. 130000 . Dette gir en årsinsidens på minst 183 per 100000 mot Haukelands 105 (1). Kan den lavere insidensen av hjerneslag ved Haukeland universitetssykehus skyldes seleksjonsmekanismer?

Barthels indeks og Rankin-skalaen ble brukt for å dokumentere at få av pasientene har rehabiliteringsbehov. Disse instrumentene har dårlig følsomhet for moderate og milde symptomer etter slag. Slike symptomer kan likevel gi store problemer for pasienter og pårørende hvis de ikke blir diagnostisert og behandlet. Vi har vist at blant pasienter med lakunære slag har over halvparten kognitive symptomer i akuttfasen (4). For en slagenhet som tar mål av seg til å behandle alle slagpasienter, er det viktig å ha solide rutiner for tverrfaglig utredning og rehabilitering som også omfatter de «usynlige» utfallene.

Det er uheldig hvis man ser en motsetning mellom hyperakutt reperfusjonsbehandling og etablert slagenhetsbehandling. Vi ser ingen slik motsetning. Oslo universitetssykehus vektlegger tverrfaglig utredning og tidlig rehabilitering av pasienter med hjerneslag og tilbyr samtidig reperfu- sjonsbehandling til mer enn $20 \%$ av pasientene. Den etablerte slagenhetsmodellen er ikke blitt uaktuell selv om hyperakutt slagbehandling har gjort store fremskritt. Hvis vi optimistisk anslår at $30 \%$ av pasientene med hjerneinfarkt kan få trombolytisk behandling og at halvparten av disse blir tilnærmet symptomfrie (5), står vi tilbake med $85 \%$ som enten er uaktuelle for slik behandling eller ikke vil oppleve full restitusjon. I tillegg kommer pasientene med blødning. Det er sterkt kunnskapsgrunnlag for at disse pasientene har nytte av slagenhetsbehandling, inkludert intensiv og umiddelbar rehabilitering. Norske og internasjonale retningslinjer slår fast at slagenheten utgjør basis for vitenskapelig dokumentert slagbehandling.

\section{Torgeir Bruun Wyller}

Geriatrisk avdeling

Oslo universitetssykehus

\section{Brynjar Fure}

Nasjonalt kunnskapssenter for helsetjenesten og

Geriatrisk avdeling

Oslo universitetssykehus

Torgeir Bruun Wyller (f. 1960) er spesialist $i$ indremedisin/geriatri. Han er overlege ved Geriatrisk avdeling og professor i geriatri ved Universitetet i Oslo.

Ingen oppgitte interessekonflikter.

Brynjar Fure (f. 1959) er dr.med. og spesialist i nevrologi og indremedisin/geriatri. Han er forskningsleder ved Nasjonalt kunnskapssenter for helsetjenesten og overlege ved Geriatrisk avdeling.

Ingen oppgitte interessekonflikter.

Litteratur

1. Næss H, Waje-Andreassen U, Brøgger J et al. Pasienter med akutt hjerneinfarkt innlagt i slagenhet. Tidsskr Nor Legeforen 2011; 131 814-8

2. Thomassen L, Waje-Andreassen U, Næss $\mathrm{H}$ et al. Behandling av cerebrovaskulære sykdommer i slagenhet. Tidsskr Nor Legeforen 2011; 131: i slagenhet.
$819-23$.

3. Brean A. Prestisje og prioritering. Tidsskr Nor Legeforen 2011; 131: 799 .

4. Fure B, Engedal K, Wyller TB et al. Cognitive impairments in acute lacunar stroke. Acta Neurol Scand 2006; 114: 17-22.

5. Lees KR, Bluhmki E, von Kummer R et al. Time to treatment with intravenous alteplase and outcome in stroke: an updated pooled analysis of ECASS, ATLANTIS, NINDS, and EPITHET trials. Lancet 2010; 375: 1695-703.

\section{Forskning på lavdosert naltrekson}

Raknes \& Giverhaug hevder i kronikken Naltrekson - høye forventninger til lave doser i Tidsskriftet nr. 8/2011 at lavdosert naltrekson kan være et billig alternativ til dyre biologiske legemidler ved blant annet multippel sklerose, og at dette bør stimulere til forskning i regi av det offentlige (1). Forfatterne hevder også at farmasøytisk industri ikke er interessert i studier på lavdosert naltrekson fordi patentet har gått ut, slik at det ikke er penger å tjene.

Dette er påstander som ikke bør stå uimotsagt. Ut fra dagens kunnskap er det lite sannsynlig at lavdosert naltrekson har effekt i nærheten av nye selektivt immunmodulerende og antiinflammatoriske midler, som blokkerer molekyler eller eliminerer cellepopulasjoner som spiller nøkkelroller i sykdomsprosessen ved multippel sklerose (2). Dette betyr ikke at lavdosert naltrekson i utgangspunktet bør forkastes, og $i$ en studie har man påvist en viss effekt på dyremodellen for multippel sklerose (3). Fordi den immunmodulerende effekten ser ut til å være relativt moderat, vil en eventuell plass for lavdosert naltrekson mest sannsynlig være som tillegg til etablert behandling. En studie av tilleggseffekt kan være mulig å organisere i samarbeid med industrien, dersom prekliniske data, data fra dyrestudier og pilotstudier er tilstrekkelig lovende. For eksempel er høydosert vitamin $D$ under utprøvning som tillegg til interferon- $\beta$ ved multippel sklerose, selv om vitamin D ikke er patentbeskyttet. Denne studien bygger på mange års forskning som har sannsynliggjort at vitamin D er viktig i sykdomsprosessen ved multippel sklerose. Tilsvarende holdepunkter for lavdosert naltrekson er imidlertid langt mer sparsomme.

Immunologisk forskning har gitt ny innsikt i sykdomsmekanismen ved multippel sklerose og andre immunologiske sykdommer og identifisert angrepspunkter for blant annet monoklonale antistoffer (2). Nye preparater blir nødvendigvis dyre, blant annet fordi store utgifter til forskning skal tjenes inn. Å prioritere offentlige forskningsressurser ut fra prisen på substansen er et blindspor. En klinisk randomisert studie av lavdosert naltrekson vil nødvendigvis bli kostbar, selv om den finansieres av det offentlige. Hvor rimelig blir egentlig behandlingen da?

Offentlige ressurser bør snarere brukes til innovative prosjekter som retter seg mot sykdommens etiologi og patogenese, og prosjektene må prioriteres ut fra vitenska- 
pelige kriterier. Prioritering ut fra et et kortsiktig ønske om å spare penger vil i lengden kaste lite av seg.

\section{Trygve Holmøy}

Nevrologisk avdeling

Akershus universitetssykehus

Trygve Holmøy (f. 1960) er spesialist i nevrologi og overlege ved Nevrologisk avdeling. Ingen oppgitte interessekonflikter.

\section{Litteratur}

1. Raknes G, Giverhaug T. Naltrekson - høye forventninger til lave doser. Tidsskr Nor Legeforen 2011; 131: $844-6$.

2. Holmøy T, Celius EG. Utvikling av ny behandling for multippel sklerose. Tidsskr Nor Legeforen 2011. 131: $832-6$.

3. Zagon IS, Rahn KA, Turel AP et al. Endogenous opioids regulate expression of experimental autoimmune encephalomyelitis. A new paradigm for he treatment of multiple sclerosis. Exp Biol Med 2009; 234: 1383-92.

\section{Behandle oss som eldre piloter!}

I Tidsskriftet nr. 8/2011 tar Lars Tjensvoll for seg temaet eldre leger og lisens (1) etter at det har vært debatt om dette i Tidsskriftet i lengre tid (2-6). Etter hans mening bør det av forsvarlighetshensyn være en øvre aldersgrense for legers autorisasjon - slik det for eksempel er for piloter og yrkessjåfører og bilførere generelt. Han hevder at veitrafikkloven stopper yrkessjåfører når de er 75 år. Deretter må de ha legeattest. Vanlige bilførere må ha helseattest etter fylte 70 år. Piloter og flygeledere stoppes når de er 65 år uansett helsetilstand. Så føyer han til: Hva gjør leger annerledes enn disse?

Nå er det bare slik at:

- yrkessjåførene mister ikke førerkortet sitt

- piloter mister ikke flysertifikatet sitt, de kan fortsatt fly så mye de lyster - til privat bruk

- den vanlige bilfører får beholde sitt førerkort etter «bestått» legesjekk

Akk ja, hadde vi bare blitt behandlet som disse! Lars Tjensvoll hevder det er naturlig at vi leger mister autorisasjonen når vi blir 75 år, men at vi unntaksvis kan få lisens til fortsatt praksis forutsatt at vi ikke lider av demens, nevrologisk sykdom, symptomgivende kreft, psykiatrisk sykdom, synsforstyrrelse og annet som kan påvirke vår vurderingsevne (en utenkelig tilstand hos leger under 75 år).

Jeg gikk innom et apotek for å be om $8 \mathrm{ml}$ Sofradex øredråper. Det var tre dager etter jeg hadde fylt 75 år. Med klar røst ble jeg gjort oppmerksom på at jeg var fratatt min autorisasjon, så de kunne dessverre ikke hjelpe meg. 18. mars var jeg fullt tilregnelig, uten demens, psykiatrisk sykdom, symptomgivende kreft, nevrologisk sykdom eller synsforstyrrelse. To dager etter tilhørte jeg tydeligvis minst én av disse kategoriene. Jeg ble nemlig 75 år 19. mars.
For ordens skyld: Dette angår ikke retten til å kunne drive praksis med tilskudd eller å være ansatt på institusjon ol. Dette handler om retten til å kunne ta ut medisiner til eget bruk. Slik det til privat bruk er tillatt for pilotene å kjøre fly og yrkessjåførene å kjøre bil.

\section{Einar Skatteboe}

Bærum

Einar Skatteboe (f. 1936) er spesialist i samfunnsmedisin og pensjonert lege. Ingen oppgitte interessekonflikter.

\section{Litteratur}

1. Tjensvoll L. Eldre piloter, yrkessjåfører - og leger. Tidsskr Nor Legeforen 2011; 131: 803

2. Hagen S. Samfunnets hån mot eldre leger. Tidsskr Nor Legeforen 2009: 129: 311-12.

3. Aasland OG, Bringedal B, Ronge K. Aldersgrense for legers autorisasjon og lisens. Tidsskr Nor Legeforen 2010; 130: 1917-20.

4. Bruusgaard D. Forsvarlighet og autorisasjon Tidsskr Nor Legeforen 2010; 130: 1906.

5. Janbu T. Eldre leger og lisens. Tidsskr Nor Legeforen 2011; 131: 111

6. Hagen S. Hvor er Legeforeningen? Tidsskr Nor Legeforen 2011; 131: 13-4.

\section{På kant med Kant?}

I Tidsskriftet nr. 11/2011 (1) antyder filosofiprofessor Jens Saugstad ved Universitetet i Oslo at vår forskningsgruppe i en artikkel i Science (2) og i en popularisert omtale av denne i Tidsskriftet (3) ikke viser respekt for andre fag. Vi beklager at han føler det slik. Vi har ikke skrevet våre vitenskapelige arbeider med den hensikt å fornærme enkeltpersoner eller et helt fagfelt.

Vi blir kritisert for vår henvisning til filosofen Immanuel Kants skrifter i forbindelse med resultater som tyder på et medfødt grunnlag for stedsans. Saugstad refererer til vår artikkel i Science, der vi brukte nevrofysiologiske metoder til å studere utviklingen av hjernens navigasjonssystemer (2). I innledningen til artikkelen står det en henvisning til Kant: «it has remained unclear whether rat pups form any representation of the local environment at the onset of outbound exploration, (...) as would be expected if the spatial representation system is preconfigured» (2). I det siste setningsleddet refereres det til Kant.

Her kan det være nyttig med en avklaring av terminologi. Den siterte setningen sier at spatiale representasjoner er prekonfigurerte. Dette betyr ikke at disse representasjonene er medfødte; det betyr bare at de er til stede før rotten begynner å utforske et spatialt miljø for første gang, helt i tråd med Kants ideer. I prinsippet kan de være et resultat av tidlig modning eller læring. Saugstad antar videre at vi med representasjon mener det samme som Kant. Imidlertid brukes representasjon i nevrobiologi om all nevral aktivitet som uttrykker egenskaper ved omverdenen. Det har ingenting å gjøre med hva rotten eventuelt skulle forestille seg subjektivt. Når det gjelder den populariserte omtalen i Tidsskriftet (3), kan vi være enig $i$ at referansen til medfødte egenskaper var upresis, selv om formålet var å forenkle. Det kan i tillegg være verdt å notere seg at Science-artikkelen ledsages av en kommentarartikkel skrevet av Kant-eksperten Linda Palmer, der hun diskuterer sammenhengen mellom våre empiriske funn $\mathrm{og}$ Kants filosofi (4). Artikkelen hennes ender slik: «Kant believed he had established the a priori (and not merely innate) status of space as a «transcendental condition» of our representation of the world. This is, however, quite compatible with the existence of a neurobiological substrate of the mental functions he identifies, so he would likely be fascinated and delighted by these investigations» (4).

Filosofiske diskusjoner bidrar til akademisk kunnskapsutvikling, og vi håper at denne diskusjonen også vil bidra.

\section{Tale Litleré Bjerknes}

May-Britt Moser

Norges teknisk-naturvitenskapelige universitet

Tale Litleré Bjerknes (f. 1989) er medisinstudent ved Norges teknisk-naturvitenskapelige universitet.

Ingen oppgitte interessekonflikter.

May-Britt Moser (f. 1963) er psykolog og professor i nevrovitenskap ved Kavli-instituttet og Senter for hukommelsesbiologi, Norges teknisk-naturvitenskapelige universitet. Ingen oppgitte interessekonflikter.

Litteratur

1. Saugstad J. Galt om Kant. Tidsskr Nor Legeforen 2011; 131: 1072

2. Langston RF, Ainge $J$ et al. Development of the spatial representation system in the rat. Science 2010; 328: 1576-80

3. Hem E. Kartlegging av hjernens navigasjonssystemer. Tidsskr Nor Legeforen 2011; 131: 654

4. Palmer L, Lynch $G$. A Kantian view of space. Science 2010; 328: 1487-8.

\section{RETTELSE}

Rettferdig tilgang til traumeforskning.

Marius Rehn, Hans Morten Lossius

Tidsskr Nor Legeforen 2011; 131: 669

I Tidsskriftet nr. 7/2011 s. 669 skulle det i denne kommentaren under oppgitte interessekonflikter stått:

Oppgitte interessekonflikter: Forfatterne er ansatt i Stiftelsen Norsk Luftambulanse, som finansierer og garanterer økonomisk for Scandinavian Journal of Trauma, Resuscitation and Emergency Medicine. Hans Morten Lossius er redaktør i dette tidsskriftet. 